\title{
METHODS TO REVIVE AND REVITALIZE THE INTEREST OF STUDENTS TOWARDS BASIC SCIENCES
}

\author{
S.N. Shobha Devi*
}

India is one of the developing countries with rich human resources. It has proved its achievements in the field of research by launching its space vehicle with the help of indigenous rocket. The contribution of scientist and engineers go together in achieving this benchmark. The progress of science and technology is the result of human resource development. At this instant one must be aware of the fact that, the progress of technology alone without basic science will not bring fruifful result. It is also true that the computer revolution in $20^{\text {th }}$ century has made remarkable changes in social life. This was made possible by the semiconductors. The improvement of semiconductors belongs to the study of basic science. The foundation for the development of information and technology is basic science. The basic science plays a key role in all aspects like manufacturing microwave oven to be used in kitchen to design of rocket and space vehicles to be sent to other planets.

According to recent estimates, the popularity of professional courses has very bad impact on progress of basic sciences. In future getting good scientists has become the most challenging endeavor in the field of science. This is because the number of students enrolling themselves to study the basic science is deteriorating. One of

Selection Grade Lecturer, Physics Dept., B.M.S. College for Women, Basavanagudi, Bangalore - 560004 
the reasons for this deterioration is the lack of job opportunities and even if appointed the remuneration package is nof up to the expectation, whereas, a candidate soon after completing his professional course will have an opportunity to get absorbed in industries and companies. These professionals have an opportunity of ESOP (Employees Stock Option) which in long run reap him/her great growth potential.

Ninety percent of students including the children of professors of basic sciences opt to go for professional courses for the above mentioned reasons. Who is responsible for this? Is it the students, or parents, or teachers, or government? This can be overcome from the following:

Some students change their combination of science subjects to arts and commerce subjects. Lack of understanding the subject is one of the reasons to change their course from science to other faculties. Lack of communication by the teachers and thinking skill of students both are responsible for decreasing the strength of science students. In the context of globalisation of higher education one must give importance to the development of basic sciences.

In the present curriculum system, pre-degree qualification is +2 level, in which study of four optional subjects is made compulsory. The degree course comprises of three optional subjects which is compulsory for all the three years/six semesters. This kind of curriculum system can be changed. During the first year (two semesters) three basic subjects can be made compulsory. During the last two years $\left(5^{\text {th }}\right.$ to $8^{\text {th }}$ Semester) the focus must be given to a particular subject so that the students will have liberty to choose the subject of their interest and pursue the higher studies in their favorite subject. This will not only attract the students to study basic science, but also enhance the research level in our country.

The educational institutions should encourage the students who opt for science education by offering attractive scholarships and freeship. The prospectus of the college should contain the openings available for a science student after completing the course in science faculty.

The students of science should be made available with the relevant books through book banks since many students hail from middle class family and can not afford to buy the precious books. They must be encouraged to avail the internet facility available to source the knowledge of science and methods to understand in a better and easy way.

The Govt/Universities and Management of Public Sector Undertakings should encourage students of basic science for pursuing research work. The research 
institutes like - CPRI (Central Power Research Institute, RRI (Raman Research Institute), IISc (Indian Institute of Science), IIA (Indian Institute of Astrophysics), ISRO (Indian Space Research Organisation) etc... and factories like - BEL, ITI, HAL, NAL etc.. should involve in curriculum design of basic science.

The study of basic science must offer an attractive career to enterprising youngsters in the world of competitions. The educational institutions and Universities should have constant touch with the leading industries/organizations and arrange for campus recruitment.

The campus recruitment for science students is possible if and only if the curriculum of basic science undergo a drastic change. The Universities should revise the syllabus of the curriculum keeping in view the demand and need of the employment market.

The revision of syllabus does not mean just changing the order of the chapter and inclusion/exclusion of some chapters by the senior most professors without the involvement of core teaching faculty. The syllabi revision committee should consist of atleast one representative from the concerned industry/organization. The views and requirements of the industry should be considered by the committee while revising the syllabus. The Universities and leading educational institutions should have constant linkage with the industries and organizations and frequent seminars and workshops will help in this direction. The workshops and seminars should be arranged by involving the basic science teachers and encourage them to come out with new ideas and methods using their creativity. The basic teaching fraternity should be given training and other skill developing techniques to teach the students using simple methods, thereby the student should understand the subject in a better manner.

The empathetic steps must be taken by the government to implement the above mentioned methods to attract the students to study basic sciences. The cooperation of students, parents, teachers, institutions, universities, industries/organization is very much essential to uplift the level of research in our country. This will further enhance the growth of information and technology. 